\title{
Population genetic structure of Garcinia imberti Bourd. an endangered endemic tree of southern Western Ghats, India
}

\author{
Anto $\mathrm{M}^{1}$, Angala $\mathrm{M}^{1}$, Jothish $\mathrm{P} \mathrm{S}^{1}$, Rameshkumar $\mathrm{K} \mathrm{B}^{2}$, Padmesh $\mathrm{P}^{3}$ \& Anilkumar $\mathrm{C}^{1^{*}}$ \\ ${ }^{1}$ Division of Conservation Biology, ${ }^{2}$ Phytochemistry and Phytopharmacology Division, Jawaharlal Nehru Tropical Botanic Garden and Research \\ Institute, Palode, Thiruvananthapuram 695 562, Kerala, India \\ ${ }^{3}$ Department of Genomic Science, School of Biological Science, Central University of Kerala, Kasaragod 671 316, Kerala, India \\ *Email: canildeepa@yahoo.co.in
}

\section{ARTICLE HISTORY}

Received: 22 January 2020

Accepted: 16 March 2020

Published: 19 July 2020

\section{KEYWORDS}

Agasthyamala Biosphere Reserve Conservation

Gene flow

Genetic diversity

ISSR markers

\begin{abstract}
Assessing the genetic diversity of endemic plants is of great importance in future conservation programmes. The genetic diversity in Garcinia imberti from Agasthyamala Biosphere Reserve of southern Western Ghats was assessed through ISSR markers by molecular characterization with 15 primers. A total of 157 accessions from six populations were used for the study. They generated 102 amplified products, out of which 89 were polymorphic (87.25\%). It produced an average of 6.8 bands per primer and $5.93 \%$ polymorphism per primer. The present study revealed that G. imberti has moderate level of genetic diversity at species level but differs at population level. The dendrogram constructed following UPGMA exhibited that all accessions were clustered together except Poonkulam population. The genetic diversity analysis of $G$. imberti showed that even though the populations are closely associated, every population have their own characteristic diversity and should be conserved. Among the populations, Chemunji is the largest one with more genetic diversity and may conserve as the potential source of gene pool of this species.
\end{abstract}

\section{Introduction}

The Western Ghats of India, one of the major biodiversity hotspots, harbours approximately 1275 exclusively endemic plant species of which more than $20 \%$ are tree species (1). Successful conservation strategies of such endemic plant species depend on their life history characteristics, ecological interaction with other organisms in their habitat and in part on the geographical distribution of genetic diversity $(2,3)$. Narrowly endemic species are susceptible to low genetic diversity and its negative consequences (4) such as inbreeding depression and loss of evolutionary potential. Populations with low genetic variation have reduced capability to adapt in the continuously changing environment and may result in reduction of population size and eventual extinction $(3,5,6)$. Recent simulation model studies expected that an atmospheric temperature increase of $2-3^{\circ} \mathrm{C}$ over the next century would result in as many as half of the world's flora being endangered with extinction (7).
Hence, knowledge on the percentage of genetic variation within and among the population of the concerned species, and the identification of populations with more genetic diversity and evolutionary potential, can provide essential information for the development of effective conservation practices. For example, an understanding on pattern of genetic diversity can help to determine which populations are genetically poor (8), whereas other populations having genetically diverse alleles and these populations may be appropriate sources for augmentation of populations (9). Accordingly, information on genetic patterns can predict the effectiveness of common management strategies, and how best to carry out those strategies. Also, recent approaches on conservation and restoration of plants may apply to preserve the genetic diversity of plant populations. This is more relevant to rare and endangered plant populations as they are usually with narrow distribution, small population sizes and geographic isolation.

(C) Anto et al (2020). This is an open-access article distributed under the terms of the Creative Commons Attribution License, which permits unrestricted use, distribution, and reproduction in any medium, provided the original author and source are credited (https://creativecommons.org/licenses/by/4.0/).

To cite this article: Anto M, Angala M, Jothish P S, Padmesh P, Anilkumar C. Population genetic structure of Garcinia imberti Bourd. an endangered endemic tree of southern Western Ghats, India. Plant Science Today. 2020;7(3):424-431. https://doi.org/10.14719/pst.2020.7.3.734 
Garcinia imberti is an endemic tree restricted to the southern tip of the Western Ghats of India with endangered status as per IUCN Red List of Threatened Plants (10). This dioecious tree grows up

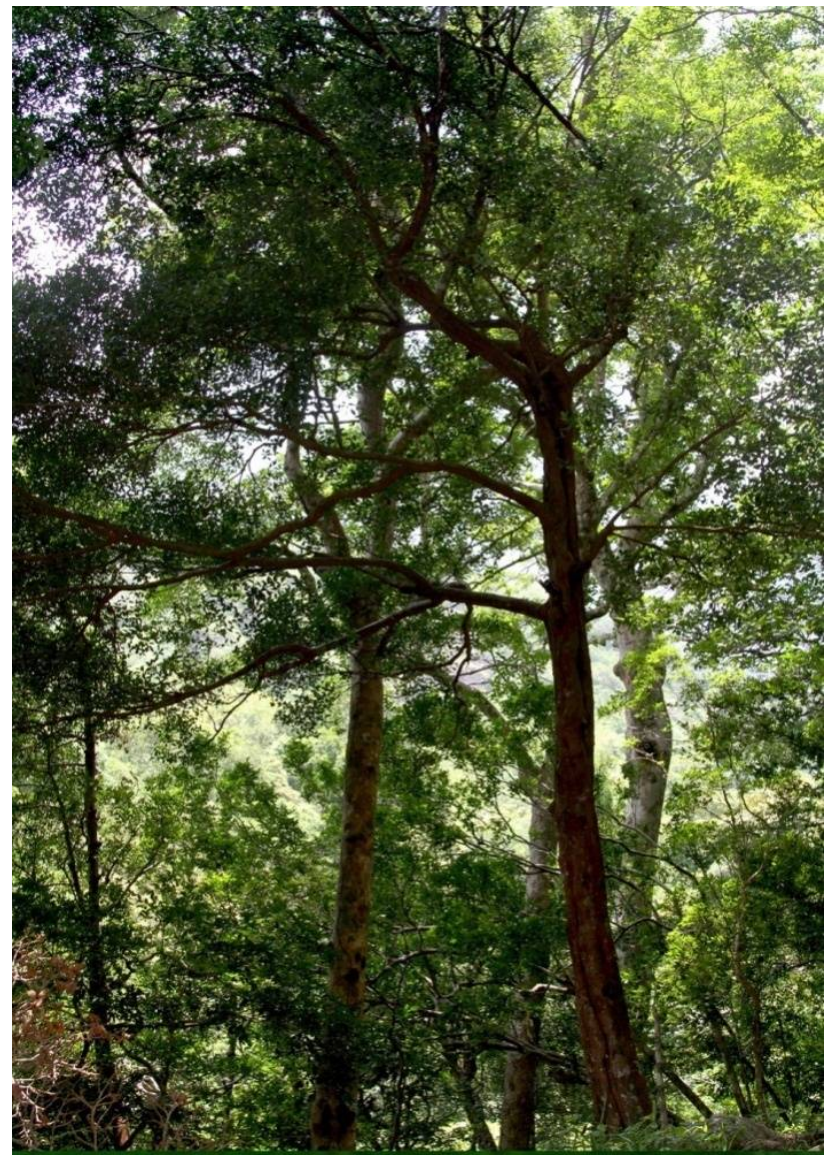

Fig. 1. Habit of Garcinia imberti Bourd.

to a height of $25 \mathrm{~m}$ in moist evergreen forests (Fig. 1). Male flowers borne on terminal racemose fascicles with 3-11 flowers and female flowers are usually solitary and borne on tip of branches. It was observed that, the populations are slightly female biased exhibiting more female trees to male trees
(1.5:1.1). Flowering occurs from February to April and cross pollinated but fruits were also produced apomictically. $G$. imberti is found as scattered populations in evergreen forests. Previous study by Manikandan (11) recorded only about 127 adult trees of $G$. imberti in Agasthyamala hills and adjacent forest areas. Habitat loss due to expansion of tea plantations together with extensive fuel wood collection and modification of habitats are the primary threat identified for its endangered status (11). Hence, an empirical evaluation of population genetic variability is essential for a successful conservation of endangered plants (12) like $G$. imberti. The objective of the present study is to assess the percentage and distribution of genetic diversity within and amongst the population of $G$. imberti using ISSR markers, inorder to achieve the goal of preserving the species as a whole with the specific question whether there are any significant differences in genetic diversity within and among populations. Local tribal people used the bark of this tree boiled in water as analgesic and antiseptic for wounds.

\section{Materials and Methods}

Sampling: Fresh young leaf samples from adult trees were randomly collected from all the six identified populations of the distributional area of $G$. imberti viz. Sankili, Cheenikkala, Ponmudi, Chemunji, Bonaccord and Poonkulam from Agasthyamala Biosphere Reserve $\left(8^{\circ} 08^{\prime}\right.$ to $9^{\circ} 10^{\prime} \mathrm{N}$ and $76^{\circ} 52^{\prime}$ to $77^{\circ}$ $34^{\prime} \mathrm{E} ; 3500.36 \mathrm{~km}^{2}$ ) of South India (Fig. 2). Among these populations, Chemunji (C) population is the larger one and continuous with more than 270 adult and immature trees, saplings and seedlings of all ages. Bonaccord (B) population is smaller one represented by about 29 adult trees and juveniles. Sankili (S) and Cheenikkala (Ch) populations are located in Shendurney Wild Life Sanctuary. Both the populations are small and have more number of adult trees (13 in Cheenikkala and 11 in Sankili) with very limited number of seedling and saplings. In all

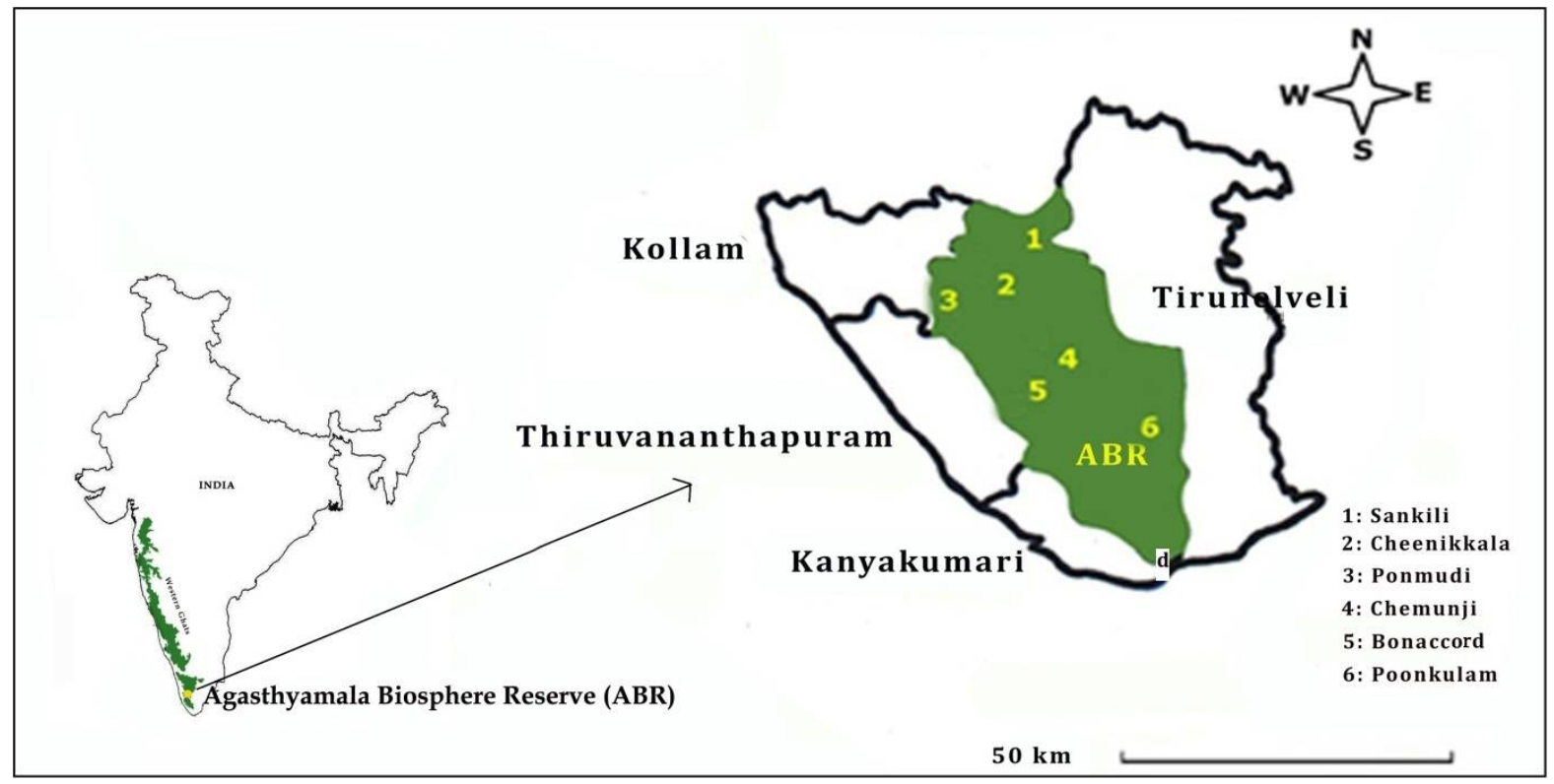

Fig. 2. Distribution map of Garcinia imberti populations at Agasthyamala Biosphere Reserve. 
the above forests, the candidate tree is growing in association with other evergreen species such as Agrostistachys borneensis, Cullenia exarillata, Palaquium ellipticum, Cinnamomum sulphuratum, $C$. chemungianum, Myristica malabarica, Litsea laevigata, Popowia beddomeana, Garcinia travancorica, G. rubro-echinata, Vateria indica and various species of Syzygium. Ponmudi (P) is a hill resort of Kerala state, adjacent to Agasthyamala hills comprising a single population of $G$. imberti located in a shola forest with few adult trees and saplings. This area is highly disturbed due to frequent tourist visits. Few trees (15 adult trees) with some seedlings were also located in Poonkulam of Kalakkad Mundanthurai Tiger Reserve (Po) of Tamil Nadu state.

Sampling was performed according to the population size and accessions were collected from both adult as well as from juveniles within a population of at least $100 \mathrm{~m}$ distance from each other and a maximum distance of $1800 \mathrm{~m}$. A total of 157 accessions were collected for genetic diversity analysis (Table 1). However, only 10 samples each could collect from Sankili, Cheenikkala, and Poonkulam populations (Table 1) as they are small as well as the individuals are so close to each other and are of same age. Leaf samples were collected and
Kollam District, Cheenikkala, 19 March 2016, Anto Mathew 88415 (TBGT); Cheenikkala, 19 March 2016, Anto Mathew 88416 (TBGT); Thiruvananthapuram District, Attayar, 30 April 2016, Anto Mathew 88417 (TBGT); Thiruvananthapuram District, Pongalappara, 20 December 2019, Anto Mathew 88426 (TBGT); INDIA, Tamil Nadu, Tirunelveli District, Poonkulam, 18 December 2019, Anto Mathew 88427 (TBGT).

\section{Genomic DNA isolation}

The genomic DNA of $G$. imberti was isolated from the freeze dried leaf tissues as per the modified CTAB (Cetyl Trimethyl Ammonium Bromide) method (14). The isolated DNA samples were resuspended in 1xTE buffer of $100 \mu \mathrm{l}$ (pH 8.0) after ethanol precipitation and kept at $-20^{\circ} \mathrm{C}$ for future analysis. The extracted DNAs were quantified spectrophotometrically by taking the absorbance at $260 \mathrm{~nm}$ using Biophotometer (Eppendorf, Hamburg). The extract of DNA was diluted to $5 \mathrm{ng} / \mu \mathrm{L}$ for PCR (polymerase chain reactions) amplification.

\section{ISSR amplification}

Fifteen random ISSR primers were selected, which produced clear and reproducible fragments and were used for the final analysis (Table 2). The PCR reaction mixture was prepared to $25 \mu \mathrm{l}$ volume containing 50 ng of DNA template, $0.2 \mathrm{mM}$ dNTP mix, $1 \mathrm{X}$ reaction

Table 1. Characteristics of Garcinia imberti populations

\begin{tabular}{|c|c|c|c|c|c|c|}
\hline Populations & Sankili & Cheenikkala & Ponmudi & Chemunji & Bonaccord & Poonkulam \\
\hline Latitude N & $8^{\circ} 47^{\prime} 48.90^{\prime \prime}$ & $8^{\circ} 47^{\prime} 46^{\prime \prime}$ & $8^{\circ} 45^{\prime} 50.2^{\prime \prime}$ & $8^{\circ} 41^{\prime} 28.0^{\prime \prime}$ & $8^{\circ} 45^{\prime} 25^{\prime \prime}$ & $8^{\circ} 38^{\prime} 20.87^{\prime \prime}$ \\
\hline Longitude E & 77¹1’45.44”' & $77^{\circ} 9^{\prime} 2^{\prime \prime}$ & $77^{\circ} 06^{\prime} 48.5^{\prime \prime}$ & $77^{\circ} 11^{\prime} 04.8^{\prime \prime}$ & $77^{\circ} 11^{\prime} 20^{\prime \prime}$ & $77^{\circ} 15^{\prime} 59.79^{\prime \prime}$ \\
\hline Vegetation- type & $\begin{array}{r}\text { Tropical } \\
\text { evergreen } \\
\text { forest }\end{array}$ & $\begin{array}{r}\text { Tropical } \\
\text { evergreen } \\
\text { forest } \\
\end{array}$ & $\begin{array}{r}\text { Tropical } \\
\text { evergreen } \\
\text { shola forest }\end{array}$ & $\begin{array}{r}\text { Tropical } \\
\text { evergreen } \\
\text { forest }\end{array}$ & $\begin{array}{r}\text { Tropical } \\
\text { evergreen } \\
\text { forest }\end{array}$ & $\begin{array}{r}\text { Tropical } \\
\text { evergreen } \\
\text { forest } \\
\end{array}$ \\
\hline Number of samples collected & 10 & 10 & 27 & 82 & 18 & 10 \\
\hline Area $\left(\mathrm{km}^{2}\right)$ & 1.98 & 1.82 & 0.14 & 2.45 & 1.98 & 0.86 \\
\hline Arial distance from Chemunji population (Km) & 12.8 & 9.3 & 11.1 & 0 & 4.2 & 10.7 \\
\hline
\end{tabular}

stored in an ice bucket and transferred to a $-20^{\circ} \mathrm{C}$ deep freezer until DNA extraction (13). Herbarium specimens were prepared and deposited in TBGT (Herbarium in Jawaharlal Nehru Tropical Botanic Garden and Research Institute, Palode, Thiruvananthapuram, Kerala, India).

\section{Voucher specimens deposited in TBGT:}

INDIA. Kerala, Thiruvananthapuram District, Chemunji, 24 April 2016, Anto Mathew 88401 (TBGT); Chemunji, 29 April 2016, Anto Mathew 88402 (TBGT); Thiruvananthapuram District, Bonaccord, 18 May 2016, Anto Mathew 88403 (TBGT); Bonaccord, 18 May 2016, Anto Mathew 88404 (TBGT); Bonaccord, 18 May 2016, Anto Mathew 88405 (TBGT); Bonaccord, 18 April 2016, Anto Mathew $88406 \quad$ (TBGT); Thiruvananthapuram District, Ponmudi, 19 March 2016, Anto Mathew 88407 (TBGT); Ponmudi, 18 April 2016, Anto Mathew 88408 (TBGT); Ponmudi, 18 May 2016, Anto Mathew 88409 (TBGT); Bonaccord, 25 April 2016, Anto Mathew 88410 (TBGT); Kollam District, Sankili, 17 March 2016, Anto Mathew 88411 (TBGT); Sankili, 17 March 2016, Anto Mathew 88412 (TBGT); Sankili, 17 March 2016, Anto Mathew 88413 (TBGT); Sankili, 18 March 2016, Anto Mathew 88414 (TBGT); buffer, 20 pmol primer and 1 unit Taq DNA Polymerase (Finnzymes, India) and double distilled water. The reaction mixture concentration and PCR conditions were standardized by trials. The amplification was performed using Eppendorf Thermocycler with a hot start at $94^{\circ} \mathrm{C}$ for $2 \mathrm{~min}$; followed by denaturing at $94^{\circ} \mathrm{C}$ for $15 \mathrm{sec}$ of 35 cycles each; annealing for $15 \mathrm{sec}$ at $37^{\circ} \mathrm{C}$; and product extension time for $5 \mathrm{~min}$ at $72^{\circ} \mathrm{C}$. The amplified products were resolved in agarose gel (1.5\%) containing Ethidium Bromide in a submarine electrophoresis unit (BioRad Inc.) and visualized under Gel documentation system (15).

\section{Data Analysis}

All the readable amplified fragments from the gels were scored based on the fragment presence or absence and denoted as ' 1 ' or ' 0 ' respectively. The binary matrix was analyzed using POPGENE program version 1.31, (16) for different genetic diversity parameters like Nei's genetic distance, Nei's gene diversity at population level (h), Shannon's diversity index (I), expected number of alleles (Na), and coefficient of genetic differentiation $\left(G_{s t}\right)$. The cluster analysis was performed using the Nei's genetic 
Table 2. Primers and the number of bands produced by them used for genetic diversity analysis

\begin{tabular}{cccc}
\hline ISSR Primers & Sequence & $\begin{array}{c}\text { Maximum no. of bands produced// } \\
\text { population }\end{array}$ & $\begin{array}{c}\text { Maximum no. of polymorphic } \\
\text { bands produced/population }\end{array}$ \\
\hline 808 & AGAGAGAGAGAGAGAGC & 9 & 8 \\
823 & TCTCTCTCTCTCTCTCC & 6 & 6 \\
824 & TCTCTCTCTCTCTCTCG & 6 & 6 \\
826 & ACACACACACACACACC & 4 & 4 \\
827 & ACACACACACACACACG & 6 & 6 \\
829 & TGTGTGTGTGTGTGTGC & 5 & 5 \\
834 & AGAGAGAGAGAGAGAGYT & 8 & 6 \\
835 & AGAGAGAGAGAGAGAGYC & 9 & 7 \\
836 & AGAGAGAGAGAGAGAGYA & 7 & 6 \\
840 & GAGAGAGAGAGAGAGAYT & 9 & 6 \\
841 & GAGAGAGAGAGAGAGAYC & 7 & 7 \\
844 & CTCTCTCTCTCTCTCTRC & 8 & 7 \\
845 & CTCTCTCTCTCTCTCTRG & 7 & 5 \\
847 & CACACACACACACACARC & 5 & 5 \\
848 & CACACACACACACACARG & 6 & $\mathbf{8 9}(\mathbf{8 7 . 2 5 \% )}$ \\
\hline \multicolumn{5}{c}{ Total } & $\mathbf{1 0 2}$ & 5.93 \\
\hline
\end{tabular}

distance (dissimilarity) matrices and corresponding phenograms produced for the 157 samples using the unweighted pair group method with arithmetic averages (UPGMA) and dendrogram was constructed using MEGA software version 6. The gene flow $\left(\mathrm{N}_{\mathrm{m}}\right)$ among the populations was calculated on the assumption that the members in the populations are at random mating and be in Hardy-Weinberg equilibrium and populations follow island model described by Wright (17). Level of gene flow $\left(\mathrm{N}_{\mathrm{m}}\right)$ was estimated following Wright's $\mathrm{F}$ statistics, $F_{S T}=1 / 4$ $\left(\mathrm{N}_{\mathrm{m}}+1\right)$ from which $\mathrm{Nm}$ was calculated as $\mathrm{N}_{\mathrm{m}}=(1-$ $\left.F_{S T}\right) / 4 F_{S T}$. The $G_{s t}$ value obtained from the POPGENE analysis was substituted for $F_{S T}$ value and derived the gene flow level (18).

\section{Results}

A total of 102 amplified products were generated by the 15 primers (Table 2), of which 89 were polymorphic $(87.25 \%)$ with a mean of 6.8 bands for each primer and $5.9 \%$ polymorphism for each primer. However, different populations exhibited different percentage of polymorphic bands such as Sankili with $84.1 \%$, Cheenikkala with $86.2 \%$ Ponmudi with $74.1 \%$, Chemunji with $92.7 \%$, Bonaccord with $65.0 \%$ and Poonkulam with $92.6 \%$. The number of products produced by the primers ranged from 4 to 9; primers 808, 835 and 840 produced maximum number of amplicons (9) and primer 826 produced minimum amplicons (4) (Table 2). At species level, $G$. imberti showed moderate level of genetic diversity with a mean value of $0.41 \pm 0.1$ and ranged among different populations from 0.21 to 0.41 and Shannon's diversity index of $0.59 \pm 0.1$ (Table 3 ). The observed heterozygosity (Ho) was also high and the observed number of alleles was 2 with $100 \%$ polymorphism at species level. However, the mean value of observed heterozygosity (Ho) in the different samples of $G$. imberti was $0.41 \pm 0.00$ and the mean value of the average expected heterozygosity (He) was $0.18 \pm 0.00$. The heterozygosity values and degree of genetic differentiation $\left(\mathrm{G}_{\mathrm{st}}\right)$ is shown in Table 3 . The diversity indices of individual populations showed that, the effective number of alleles (ne) and observed number of alleles (na) across the populations were found to be $1.71 \pm 0.2$ and $2.0 \pm 0.0$, respectively (Table 3 ).

\section{Population genetic differentiation and gene flow level}

Genetic differentiation amid the populations studied ( $G_{s t}$, assuming Hardy-Weinberg Equilibrium) is 0.55, showing that the only $45 \%$ variation was found within populations (Table 3). The Nm (gene flow) values between accessions were calculated on the assumption that the study samples follows the inland model of Wright (17) which expect a connection between the number of migrants an accession receives per generation and Fst. The gene flow level estimated as 0.41 individuals per generation among populations, telling that exchange of genes between G. imberti populations was comparatively low. The individuals within Chemunji population showed high heterozygosity (Ho) and low genetic differentiation $\left(G_{\mathrm{st}}\right)$. Ponmudi population showed low rates of gene flow, high genetic differentiation and low genetic diversity.

The dendrogram constructed following UPGMA showed that accessions are clustered into two major groups and six subgroups and Poonkulam is totally distinct from other populations (Fig. 3). The dendrogram showed that accessions are clustered geographically as east (Poonkulam) and west (rest of the five populations) of the Western Ghats (Fig. 3). Among the subgroups, Sankili and Cheenikkala are distant than other populations. All accessions from Chemunji population come under the same clade of the dendrogram showed genetically alike accessions. Accessions from Ponmudi populations showed two separate clades, and showed proximity to Sankili Cheenikkala populations.

\section{Discussion}

Population genetic structure defined as the group of individuals which share a common gene pool, determines the capacity to be enhanced or altered by selection (19). The present study showed that $G$. 
Table 3. Different genetic diversity indices assayed in Garcinia imberti

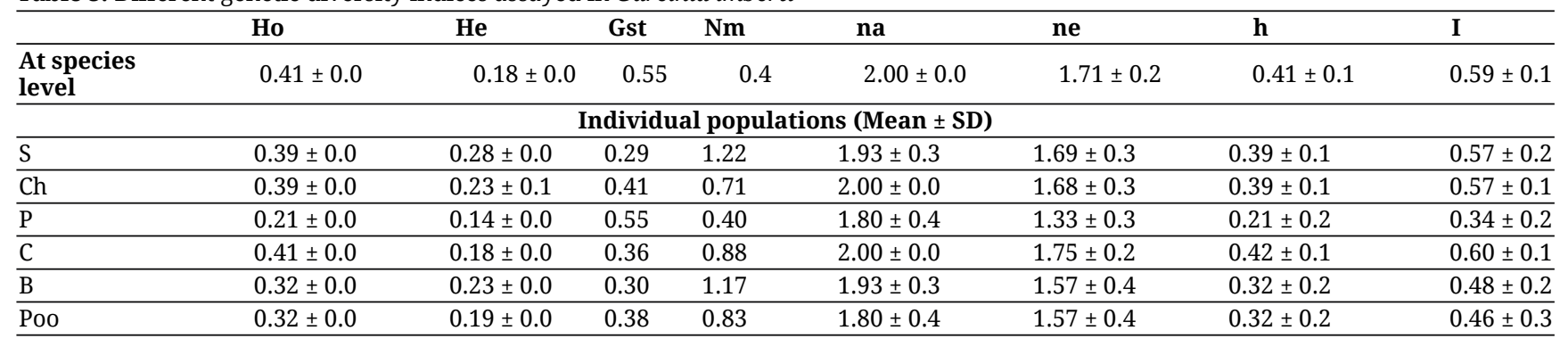

(S- Sankili; Ch- Cheenikkala; P- Ponmudi; C- Chemunji; B- Bonaccord and Poo- Poonkulam; na- observed number of alleles; ne- effective number of alleles; h- Nei's (1973) gene diversity; I- Shannon's diversity index; Ho- observed heterozygosity; He- expected heterozygosity; ${ }_{\text {st }}{ }^{-}$ genetic differentiation and $\mathrm{Nm}$ - gene flow)

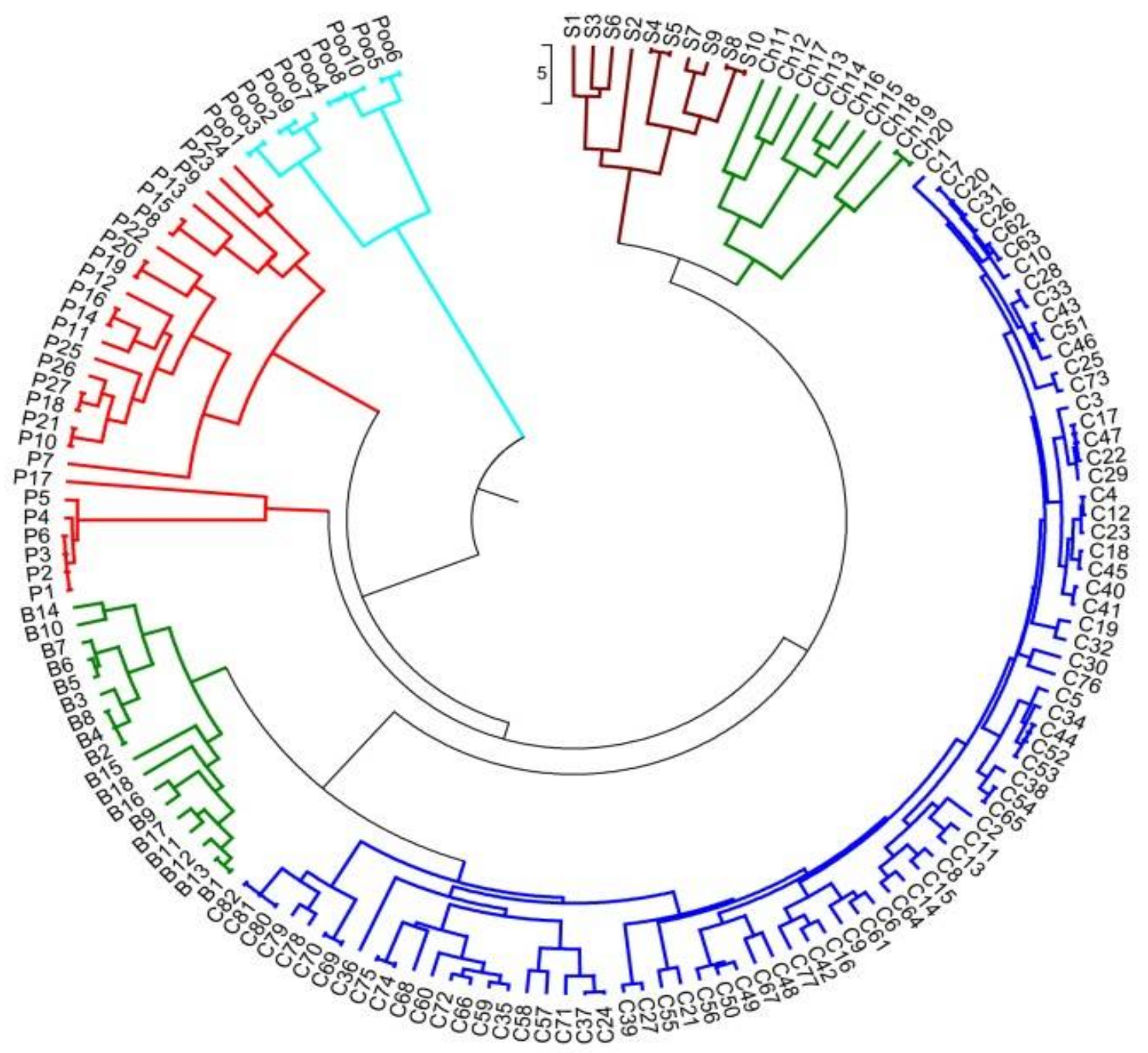

Fig. 3. Dendrogram of genetic diversity analysis on Garcinia imberti

(S- Sankili; Ch- Cheenikkala; P- Ponmudi; C- Chemunji; B- Bonaccord; Poo- Poonkulam).

imberti has moderate level of genetic diversity. Genetic diversity is one of the fundamental evolutionary variables that associate with size and viability of population and the persistence of species. As an endemic tree species, the expected heterozygosity (Ho) of $G$. imberti within populations was high. Knowledge of genetic diversity within and between populations offers essential information for the development of appropriate management strategies focused towards their protection (20). In $G$. indica, another endemic of the Western Ghats, exhibited low levels of genetic diversity and was attributed to apomixis as most plants are derived not by cross pollination (21). Similar type of observations were reported in $G$. atroviridis, endemic to Peninsular Malaysia (22). However, the high level of genetic variation in $G$. cambogia observed the accessions from geographically distinct Kerala regions could be due to outcrossing by insects, which causes the higher gene flow rate within and among the populations (23).

Different parameters of genetic diversity such as percentage of polymorphism, Nei's genetic diversity, Shannon's diversity index and average heterozygosity were moderately high in the present 
study. This results reveals that $G$. imberti have moderate genetic diversity similar to some other endemics such as Poeciloneuron pauciflorum (24), Agave victoriae-reginae (25), Antirrhinum charidemi and $A$. valentinum (26). The Shannon's diversity index varies from 0 to 1 , and high genetic diversity is indicated by values closer to 1 (27). It was reported that the degree of polymorphic locus is not an applicable measure of the genetic variation and thus, the heterozygosity (genetic diversity) is more important (28). Reports are on the genetic diversity between the accessions of Varronia curassavica obtained Shannon's diversity index i.e., 0.42, polymorphism i.e., 97.98\%, expected heterozygosity of 0.27 using 14 primers (29). Reports are also on the plant species with separate sex, the overall within population genetic diversity was moderate since biased sex ratios may harmfully affect the genetic diversity due to higher genetic drift (30). This may also applicable to the dioecious $G$. imberti populations with slightly female biased sex ratio (personal observation).

Maintenance of genetic variability of an endangered plant species is one of the major aims for conserving that species (31). The analysis of population genetic structure and reproductive capacity of $G$. imberti have imperative implications for conservation strategies. The distribution of genetic diversity plays a significant role for conserving species composition $(32,33)$. There are studies revealing that determining the highest conservation value of a population is not that simple (34). The present study showed that Chemunji population with high allele richness and genetic diversity indicated the occurrence of cross breeding and comparatively more gene flow than other populations. Allelic richness is a direct measure of genetic diversity that target at selecting the populations for conservational importance $(35,36)$. The maximum $G_{\text {st }}$ value signified the level of genetic differentiation among the populations (37).

The G. imberti samples from different forest ranges of Agasthyamala Biosphere Reserve showed the clustering according to the spatial arrangement of the populations (Fig. 3). The dendrogram showed individual accessions belonging to different populations clustered distinctly indicated the genotypes were more closely allied among themselves than other populations. Except Poonkulam samples, all other samples are from western portion of the Ghats. The clustering indicated that gene flow occurred mainly within the populations rather than between populations. The geographical distance of populations restricts gene flow between populations which resulted in reduced genetic variability. According to Nybom (38), pollen and seed dispersal, geographic distribution range, successional stages and mating systems are some of the factors that can decide the percentage and distribution of genetic variability amid and within populations. Sankili and Cheenikkala are adjacent populations but more distant than other populations. An interesting observation is that, the geographical location of Ponmudi population. It is an isolated population found in a shola forest separated by large hillocks. Also, they have very less rate of gene flow and high genetic differentiation than other studied populations and genetic diversity but showed two sub-clusters indicated that they are of different origins or affected by genetic drift. In a study it was revealed that small populations of Pulsatilla patans exhibited the signs of genetic loss due to genetic drift (34). The decline of genetic diversity within populations at marginal geographical area may limit their evolutionary capability delaying adaptation to environmental factors (39-41). Isolated populations may adaptively diverge and showed reduced gene flow rate (42). Low rate of genetic diversity could lessen the plant strength and limit a population's capacity to react to varied eco-physiological influences through selection and adaptation (43).

Partitioning of genetic variation in $G$. imberti $\left(\mathrm{G}_{\mathrm{st}}\right.$ $=0.55$ ) was high with limited historical gene flow across a wide geographic range. The reduced genetic diversity between populations may be due to geographic separation and reduced gene flow $(\mathrm{Nm}=$ $<1$ ) between the uneven populations (44). Nm value of 0.41 showed that, gene flow rate between populations is limited. Since most of the populations are separated by long distance $(>8 \mathrm{~km})$, and limited gene flow (both pollen and through seeds) within and among populations are the main factor shaping the distinct genetic structure of $G$. imberti. In the longterm viewpoint, reduce in genetic variation leads to lower population adaptability and enhanced the risk of extinction under varied habitats (34). The $G$. imberti populations are suffered with small population size, reduced gene flow due to lack of pollinators and seed dispersers $(11,45)$ wide geographic separation among the populations besides various stress and slow seedling growth (46) invite serious attention to conserve the species.

\section{Conclusion}

Designing conservation strategies for endangered species require a good knowledge about the level and distribution of genetic diversity. Discontinuous distribution and small population size along with high allele richness invite serious attention to conserve the species. G. imberti populations are declining due to various stochastic effects along with slow seedling growth. If such pressure continues without sustainable and appropriate management of the genetic resources the diversity and natural abundance of the species will be declined. Complementary ex- situ conservation, propagation and cultivation methods need to be undertaken for the protection and maintenance of the existing genetic diversity of $G$. imberti. The findings can serve as a guide to preserve every similar population or species from endangerment.

\section{Acknowledgements}

The authors express sincere gratitude to the Director, KSCSTE-JNTBGRI for facilities provided and SERB-DST for financial support. The first author expresses sincere thanks to the University of Kerala for the approved Ph.D programme on $G$. imberti. The 
authors are thankful to Dr. $\mathrm{K} \mathrm{K}$ Sabu and Mr. Manikantan K, JNTBGRI for their valuable help and support throughout the work. Kerala and Tamil Nadu Forest Departments provided forest entry permit to collect and access the samples for the study.

\section{Authors' contributions}

AM and AM collected the leaf samples from the field, carried out the work, analysed the data. AM, PPP, JPS, $\mathrm{RKB}$ and $\mathrm{AC}$ interpreted the data and helped in manuscript writing.

\section{Conflict of interests}

The authors declared that they have no conflict of interest.

\section{References}

1. Nayar TS, Beegam AR, Sibi M, editors. Flowering Plants of the Western Ghats, India 1 \& 2. Jawaharlal Nehru Tropical Botanic Garden and Research Institute, Thiruvananthapuram, Kerala; 2014.

2. Holsinger KE, Gottlieb LD. Conservation of rare and endangered plants: principles and prospects. In: Genetics and conservation of rare plants. Falk DA, Holsinger KE, editors. Oxford University Press, Oxford; 1991.

3. Ellstrand NC, Elam DR. Population genetic consequences of small population size: implications for plant conservation. Annu Rev Ecol Evol S. 1993;24:217-42. https://doi.org/10.1146/annurev.es.24.110193.001245

4. Gitzendanner MA, Solitis PA. Patterns of genetic variation in rare and widespread plant congeners. Am J Bot. 2000;87(6):783-92. https://doi.org/10.2307/2656886

5. Spielman D, Brook BW, Frankham R. Most species are not driven to extinction before genetic factors impact them. P Natl Acad Sci. USA. 2004;101:15261-64. https://doi.org/10.1073/pnas.0403809101

6. Gaafar ARZ, AI-Qurainy F, Khan S. Assessment of genetic diversity in the endangered populations of Breonadia salicina (Rubiaceae) growing in the Kingdom of Saudi Arabia using inter-simple sequence repeat markers. BMC Genet. 2014;15(1):1-10. https://doi.org/10.1186/s12863-014-0109-4

7. Bramwell D. The response of botanic gardens to climate change. BG Journal. 2007; 4(2):3-8.

8. Gitzendanner MA, Weekley CW, Germain-Aubrey CC, Soltis DE, Soltis PS. Microsatellite evidence for high clonality and limited genetic diversity in Ziziphus celata (Rhamnaceae), an endangered, self-incompatible shrub endemic to the Lake Wales Ridge, Florida, USA. Conserv Genet. 2012;13(1):223-34. https://doi.org/10.1007/s10592-011-0287-9

9. Tecic DL, McBride JL, Bowles ML, Nickrent DL. Genetic variability in the federal threatened Mead's milkweed, Asclepia smeadii Torrey (Asclepiadaceae), as determined by allozyme electrophoresis. Ann Mo Bot Gard. 1998;97-109. https://doi.org/10.2307/2992000

10. IUCN. Garcinia imberti. The IUCN Red List of Threatened Species. World Conservation Monitoring Centre; 1998.

11. Manikandan G. Reproductive biology of Garcinia imberti Bourd. and G. travancorica Bedd.: endemic and endangered tree species from Agasthyamalai Biosphere Reserve. PhD Thesis. Gandhigram Rural Institute - Deemed University, Tamil Nadu; 2016.

12. Fenster CB, Dudash MR. Genetic considerations for plant population restoration and conservation. In: Restoration of Endangered Species; Conceptual Issues, Planning and Implementation. Bowles ML, Whelan CJ, editors. Cambridge
University

Press,

https://doi.org/10.1017/CBO9780511623325.004

13. Feitosa-Alcantara, Barroso R, Ana VCM, Blank AF, AlmeidaPereira CS, Carvalho SVA, Arrigoni-Blank MF. Analysis of genetic diversity of Hyptis pectinata (L.) Poit. plants using ISSR markers. Genet Mol Res. 2017;16(3):1-10. https://doi.org/10.4238/gmr16039603

14. Murray MG, Thompson WF. Rapid isolation of high molecular weight plant DNA. Nucleic Acids Res. 1980;8(19):4321-26. https://doi.org/10.1093/nar/8.19.4321

15. Almeida-Pereira, Santos C, Ana Muniz VCS, Alves RP, FeitosaAlcantara RB, Arrigoni-Blank MF, Carvalho SAV, Costa TS Genetic diversity of native populations of Croton tetradenius Baill. using ISSR markers. Genet Mol Res. 2017;16(2):1-12. https://doi.org/10.4238/gmr16029602

16. Yeh FC, Boyle TBJ, Ye ZH, Mao JX. POPGENE: The User-Friendly Software for Population Genetic Analysis. University of Alberta, Edmonton; 1999.

17. Wright S. The genetical structure of populations. Ann Eugenic 1949;15(1):323-54 https://doi.org/10.1111/j.1469-1809.1949.tb02451.x

18. Michael CW, David EM. Indirect measures of gene flow and migration: FST $\neq 1 /(4 \mathrm{Nm}+1)$. Heredity. 1999;82(2):117-25. https:// doi.org/10.1038/sj.hdy.6884960

19. Hayward MD, Breese EL. Population structure and variability. In: Plant Breeding Series. Hayward MD, Bosemark NO, Romagosa I, Cerezo M, editors. Springer, Dordrecht; 1993. https://doi.org/10.1007/978-94-011-1524-7

20. Milligan BG, Leebens-Mack J, Strand AE. Conservation genetics: beyond the maintenance of marker diversity. Mol Ecol. 1994;3(4):423-35. https://doi.org/10.1111/j.1365294X.1994.tb00082.X

21. Thatte KS, Khandekar RG, Deodhar MA. Assessment of diversity in Garcinia indica (Dupetit-Thouars.) Choisy. using morphological and molecular markers. J Trop Agr. 2012;50(12):30-36.

22. Pangsuban S, Bamroongrugsa N, Kanchanapoom K, Naulsri C. An evaluation of the sexual system of Garcinia atroviridis L. (Clusiaceae), based on reproductive features. Songklanakarin Journal of Science and Technolology, 2007;29(6):1457-68.

23. Tharachand C, Immanuel Selvaraj C, Abraham Z. Molecular insights into the genetic diversity of Garcinia cambogia germplasm accessions. Braz Arch Biol Techn. 2015;58(5):76572. https://doi.org/10.1590/S1516-89132015050197

24. Pillai PP, Sajan JS, Menon KM, Hemanthakumar AS, Pandurangan AG, Krishnan PN, Seeni S. Analysis of Genetic Diversity in Poeciloneuron pauciflorum Bedd.-An Endemic Tree Species from the Western Ghats of India. Am J Plant Sci. 2011;2(03):416-24. https://doi.org/10.4236/ajps.2011.23047

25. Martinez PA, Eguiarte LE, Furnier GR. Genetic diversity of the endangered endemic Agave victoria-reginae (Agavaceae) in the Chihuahuan Desert. Am J Bot. 1999;86(8):1093-98. https://doi.org/10.2307/2656971

26. Mateu, Segura MG. Population subdivision and genetic diversity in two narrow endemics of Antirrhinum L. Mol Ecol. 2000;9(12):2081-87 294X.2000.01119.X

https://doi.org/10.1046/j.1365-

27. da Silva RCS, Milet-Pinheiro P, da Silva PCB, da Silva AG, da Silva MV, Navarro DMDAF, da Silva NH. (E)-caryophyllene and a-humulene: Aedesa egypti oviposition deterrents elucidated by gas chromatography-electrophysiological assay of Commiphora leptophloeos leaf oil. PLoS One. 2015;10(12):1-14. https://doi.org/10.1371/journal.pone.0144586

28. Nei M. Molecular Evolution Genetics. Columbia University Press, New York;1987.https://doi.org/10.7312/nei-92038

29. Brito, FDA., Nizio, DADC., Muniz, AVCDS., Diniz, LEC., Rabbani, ARC., Arrigoni-Blank, MDF., Alvares-Carvalho, SV., Figueira, GM., Montanari Júnior, I. Blank, AF. Genetic diversity analysis of Varronia curassavica Jacq. accessions using ISSR markers. $\begin{array}{llll}\text { Genet } & \text { Mol } & \text { Res. 2016:15(3):1-10 }\end{array}$ https://doi.org/10.4238/gmr.15038681 
30. Vandepitte K, Honnay O, De Meyer T, Jacquemyn H, RoldánRuiz I. Patterns of sex ratio variation and genetic diversity in the dioecious forest perennial Mercurialis perennis. Plant Ecol. 2010;206(1):105-14. https://doi.org/10.1007/s11258-009-9627-y

31. Avise JC, Hamrick JL. (editors). Conservation Genetics: Case Histories from Nature. Chapman \& Hall, New York; 1996. https://doi.org/10.1007/978-1-4757-2504-9

32. Barrett S, Kohn J. Genetic and evolutionary consequences of small population size in plants: implications for conservation In: Genetics and Conservation of Rare Plants (editors. Falk, DA, Holsinger, KE). New York, Oxford University Press; 1991.

33. Millar CI, Libby WJ. Strategies for conserving clinal, ecotypic, and disjunct population diversity in widespread species. Genetics and Conservation of Rare Plants 1991;149-70.

34. Szczecińska M, Sramko G, Wołosz K, Sawicki J. Genetic diversity and population structure of the rare and endangered plant species Pulsatilla patens (L.) Mill in East Central Europe. PLoS One. 2016;11(3):1-24. https://doi.org/10.1371/journal.pone.0151730

35. Petit RJ, El Mousadik A, Pons O. Identifying populations for conservation on the basis of genetic markers. Conserv Biol. 1998;12(4):844-55. 1739.1998.96489.x

https://doi.org/10.1046/j.1523

36. Vinceti B, Loo J, Gaisberger H, van Zonneveld MJ, Schueler S Konrad H, Caroline ACK, Geburek T. Conservation priorities for Prunus africana defined with the aid of spatial analysis of genetic data and climatic variables. PloS one. 2013;8(3):1-16. https://doi.org/10.1371/journal.pone.0059987

37. Nilkanta H, Amom T, Tikendra L, Rahaman H, Nongdam P. ISSR Marker based population genetic study of Melocanna baccifera (Roxb.) Kurz: A commercially important bamboo of Manipur, North-East India. Scientifica. 2017;1-9. https://doi.org/ 10.1155/2017/3757238

38. Nybom H. Comparison of different nuclear DNA markers for estimating intraspecific genetic diversity in plants. Mol Ecol.
2004;13(5):1143-55.

https://doi.org/10.1111/j.1365-294X.2004.02141.x

39. Hoffmann AA, Blows MW. Species borders: ecological and evolutionary perspectives. Trends Ecol Evol. 1994;9(6):223-27. https://doi.org/10.1016/0169-5347(94)90248-8

40. Hoffmann AA, Parsons PA. Extreme Environmental Change and Evolution. Cambridge University Press, Cambridge;1997.

41. Gaston KJ. The Structure and Dynamics of Geographic Ranges. Oxford University Press, Oxford, England;2003.

42. Lenormand T. Gene flow and the limits to natural selection. In: Trends $\quad$ Ecol $\quad$ Evol. $2002 ; 17(4): 183-89$. https://doi.org/10.1016/S0169-5347(02)02497-7

43. Nybom H, Bartish IV. Effects of life history traits and sampling strategies on genetic diversity estimates obtained with RAPD markers in plants. Perspectives in Plant Ecology, Evolution and Systematics 2000;3(2):93-114. https://doi.org/10.1078/1433-831900006

44. Haque I, Bandopadhyay R, Mukhopadhyay K. Population genetic structure of the endangered and endemic medicinal plant Commiphora wightii. Mol Biol Rep. 2010;37(2):847-54 https://doi.org/10.1007/s11033-009-9661-9

45. Anto M, Jothish PS, Angala M, Anilkumar C. Fruit predation and adaptive strategies of Garcinia imberti, an endangered species of southern Western Ghats. Curr Sci India. 2018;115(12):2315-21. https://doi.org/10.18520/cs/v115/i12/23152321

46. Anto M, Angala M, Anilkumar C. Stochastic stress and survivability of Garcinia imberti Bourd. (Clusiaceae) an endangered tree of the Western Ghats, India. Journal of Traditional and Folk Practices. 2018;6(1):103-08. https.//doi.org/ 10.25173/jtfp.2018.6.1.93. 